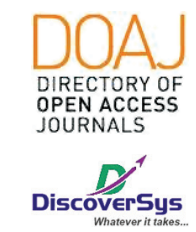

Published by DiscoverSys

\section{Displasia ektodermal tipe hipohidrotik pada seorang anak bayi tiga tahun}

\author{
I Putu Arie Sasmita, ${ }^{1,2 *}$ Luh Made Mas Rusyati
}

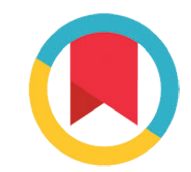

CrossMark

\title{
ABSTRACT
}

Introduction: Ectodermal dysplasia (ED) is a rare genetic disorder characterized by defect in two or more ectodermal structures such as teeth, hair, nails and sweat glands. Ectodermal dysplasia divided into 2 types, which is hidrotic and hypohidrotic. The hypohidrotic type was found in $80 \%$ of cases. There is no specific treatment for this disorder, which is more of a symptomatic measures depends on the structure involved.

Case: A 1 year old male, Balinese, consulted from Department of Pediatrics to Department of Dermatovenereology with the chief complaint of dry skin, absence of sweat, teeth, scalp hair and eyebrow since birth. Recurrent fever present especially in hot climates. No growth abnormalities. No history of incest between parents. His grandfather also complained about the same symptoms, which are sparse hair and decreased sweating. General examination revealed frontal bossing, saddle nose, prominent chin and anodontia. Dermatologic examination revealed multiple hypopigmented macules, well defined margin, oval-round shaped, size $\emptyset 0,5-1 \mathrm{~cm}$, distributed over entire skin and anhidrosis. Department of Dermatovenereology gives moisturizer every 12 hours topically. Department of Pediatrics gives zinc tablets, $20 \mathrm{mg}$ every 24 hours orally.

Conclusion:The diagnosis of ED was mainly clinical. Treatment is symptomatic and effective education is needed to increase patient's quality of life. Early fetal detection can be performed if there is a risk in the family. Currently, there is a team joined under SIDIC program in Sanglah Hospital whose main purpose is to detect and prevent congenital disorders early.

Keywordss: Ectodermal dysplasia, hypohidrotic, treatment

Cite This Article: Sasmita, I.P.A., Rusyati, L.M.M. 2019. Displasia ektodermal tipe hipohidrotik pada seorang anak bayi tiga tahun. Intisari Sains Medis 10(2): 368-374. D0I: 10.15562/ism.v10i2.413

\section{ABSTRAK}

'Program Pendidikan Dokter Spesialis 1, Ilmu Kesehatan Kulit dan Kelamin, Fakultas Kedokteran Universitas Udayana-RSUP Sanglah Denpasar, Bali-Indonesia ${ }^{2}$ Departemen/KSM IImu Kesehatan Kulit dan Kelamin, Fakultas Kedokteran Universitas Udayan-RSUP Sanglah Denpasar, Bali-Indonesia

\section{*Corresponding email: I Putu Arie} Sasmita, Program Pendidikan Dokter Spesialis 1, IImu Kesehatan Kulit dan Kelamin, Fakultas Kedokteran Universitas Udayana-RSUP Sanglah Denpasar, Bali-Indonesia, Departemen/KSM IImu Kesehatan Kulit dan Kelamin, Fakultas Kedokteran Universitas Udayan-RSUP Sanglah Denpasar, Bali-Indonesia

putu_3041@hotmail.com

Diterima: 11-02-2019

Disetujui: 16-04-2019

Diterbitkan: 01-08-2019
Latar Belakang: Displasia ektodermal (DE) merupakan suatu kelainan herediter yang jarang didapatkan dan ditandai dengan adanya defek dari dua atau lebih struktur ektodermal seperti gigi, rambut, kelenjar keringat dan kuku. Displasia ektodermal dibagi menjadi 2 tipe, yaitu tipe hidrotik dan hipohidrotik. Tipe hipohidrotik ditemukan pada $80 \%$ kasus. Tidak ada pengobatan spesifik untuk DE, dimana penatalaksanaannya lebih bersifat simptomatis tergantung struktur ektoderm yang terlibat.

Kasus: Seorang anak laki-laki berusia 1 tahun, suku Bali, dikonsulkan dari bagian Pediatri ke bagian Kulit dan Kelamin RSUP Sanglah Denpasar dengan keluhan kulit kering, tidak pernah berkeringat, tidak tumbuh gigi, rambut kepala dan alis sejak lahir. Keluhan demam hilang timbul terutama bila cuaca panas. Riwayat tumbuh kembang tidak ada gangguan. Tidak ada pernikahan sedarah antara ayah dan ibu pasien. Terdapat keluhan serupa pada kakek pasien berupa rambut dan keringat yang jarang. Pada status generalis didapatkan frontal bossing, saddle nose, dagu tampak lancip, madarosis dan anodontia. Status dermatologis, lokasi pada seluruh tubuh, didapatkan effloresensi berupa makula hipopigmentasi multipel, batas tegas, bentuk bulat, ukuran $\emptyset 0,5-1 \mathrm{~cm}$, juga didapatkan adanya anhidrosis. Dari bagian Kulit dan Kelamin diberikan pelembab tiap 12 jam topikal untuk melembabkan kulit yang kering. Bagian Pediatri memberikan terapi berupa zinc $20 \mathrm{mg}$ tiap 24 jam per oral.

Simpulan: Diagnosis DE lebih didasarkan pada gambaran klinis. Tatalaksana bersifat simptomatis disertai edukasi yang efektif terhadap pasien dan keluarganya untuk meningkatkan kualitas hidup penderita. Deteksi dini kehamilan dapat dilakukan bila ibu pasien ingin hamil kembali. Saat ini di RSUP Sanglah terdapat suatu tim yang tergabung dalam program Sanglah Birth Defect Integrated Centre (SIDIC) untuk deteksi dan pencegahan kelahiran cacat akibat penyakit bawaan.

\section{Kata kunci: Displasia ektodermal, hipohidrotik, tatalaksana}

Cite Pasal Ini: Sasmita, I.P.A., Rusyati, L.M.M. 2019. Displasia ektodermal tipe hipohidrotik pada seorang anak bayi tiga tahun. Intisari Sains Medis 10(2): 368-374. D0I: 10.15562/ism.v10i2.413

\section{PENDAHULUAN}

Displasia ektodermal (DE) merupakan suatu kelainan herediter yang jarang didapatkan, ditandai dengan adanya defek dari dua atau lebih struktur ektodermal. Ektoderm sendiri merupakan lapisan terluar sel pada perkembangan embriogenik yang berkontribusi terhadap pembentukan berbagai 
macam bagian tubuh seperti gigi, rambut, kelenjar keringat dan kuku. ${ }^{1,2}$

Displasia ektodermal dapat terjadi pada lakilaki maupun perempuan dari segala ras dan etnis. DE memiliki beberapa tipe, tapi secara garis besar dibagi menjadi 2, yaitu tipe hidrotik (fungsi kelenjar keringat masih normal) dan hipohidrotik (disertai penurunan fungsi kelenjar keringat). Prevalensi DE secara global sekitar 1 kasus dari 100.000 kelahiran, sedangkan prevalensi DE hipohidrotik yang merupakan varian tersering dari DE yaitu sekitar 80\% dari keseluruhan kasus. Pada suatu penelitian di Denmark terhadap 1.224 subjek diketahui bahwa prevalensi DE hipohidrotik adalah sebesar 21,9 per 100.000 kasus. Data lain menunjukkan bahwa pada suatu daerah kecil di Meksiko dengan 6.978 penduduk, dilaporkan terdapat sebesar 20 kasus DE hipohidrotik pada tahun 2007.1,3,4

Displasia ektodermal disebabkan oleh adanya mutasi atau delesi gen tertentu pada suatu kromosom dan dapat diturunkan secara autosomal dominan, autosomal resesif maupun $X$-linked. ${ }^{3}$ Tipe hidrotik diturunkan secara autosomal dominan, sedangkan tipe hipohidrotik terutama diturunkan secara $X$ linked. Penyebab kelainan DE tipe hipohidrotik adalah akibat adanya mutasi pada gen EDA, EDAR dan gen EDARADD. Mutasi yang terjadi ini mencegah interaksi normal antara ektoderm dan mesoderm sehingga mengganggu perkembangan normal dari rambut, kelenjar keringat dan gigi. $\mathrm{DE}$ tipe hipohidrotik terutama ditandai oleh hipodontia atau anodontia (tidak tumbuhnya gigi), hipotrikosis (pertumbuhan rambut yang jarang) dan hipohidrosis (berkurangnya produksi keringat)., ${ }^{1,4}$

Tidak ada pengobatan yang spesifik untuk DE, dimana penatalaksanaannya lebih bersifat simptomatis tergantung struktur ektoderm yang terlibat. Penatalaksanaan hipodontia atau anodontia meliputi penggunaan gigi palsu atau implan gigi. Pada keadaan kulit kering karena hipohidrosis, penggunaan emolien sangat dianjurkan. Sedangkan pada keterlibatan rambut, penggunaan rambut palsu (wig) dan minoksidil topikal dilaporkan bermanfaat. Diperlukan suatu cara perawatan dan edukasi yang efektif pada penderita DE agar dapat meningkatkan kualitas hidup penderita.

Tujuan tinjauan pustaka ini adalah untuk mendiskusikan lebih lanjut tentang penatalaksanaan dan cara perawatan penderita DE berdasarkan masing-masing struktur ektoderm yang terlibat.

\section{KASUS}

Seorang anak laki-laki berusia 1 tahun, suku Bali, warga negara Indonesia, dengan nomer catatan medis 16.01.27.28 dikonsulkan dari bagian Pediatri ke bagian Kulit dan Kelamin RSUP Sanglah
Denpasar pada tanggal 5 April 2016 dengan keluhan kulit kering sejak lahir.

Dari anamnesis didapatkan penderita dikeluhkan kulit tidak pernah berkeringat sejak lahir. Pasien juga tidak memiliki rambut kepala dan alis sejak lahir, saat berusia 1 tahun mulai tumbuh rambut di kepala namun jarang. Selain itu, sampai sekarang pasien juga dikeluhkan tidak tumbuh gigi. Keluhan demam hilang timbul sejak pasien lahir. Demam sering terjadi bila cuaca panas dan saat pasien melakukan aktivitas berlebih.

Riwayat penyakit dahulu, tidak dikeluhkan adanya penurunan produksi air mata dan air liur, riwayat kejang disangkal. Riwayat alergi makanan dan obat-obatan sebelumnya disangkal. Riwayat atopi disangkal.

Riwayat tumbuh kembang, perkembangan bicara dan berjalan dikatakan tidak ada gangguan. Saat ini sudah bisa mengucapkan beberapa kata, sudah bisa berjalan dan berdiri. Fungsi mendengar dan melihat dikatakan tidak ada gangguan.

Riwayat pengobatan, ibu pasien sering mengoleskan pelembab pada kulit pasien. Pelembab dibeli sendiri oleh ibu pasien. Riwayat pengolesan minyak tradisional lainnya disangkal.

Riwayat sosial, pasien adalah anak kedua dari dua bersaudara. Tidak ada hubungan darah antara ayah dan ibu pasien. Tidak ada keluhan yang sama pada kakak pasien, tetapi terdapat riwayat keluhan yang serupa pada kakek pasien.

Pemeriksaan fisik didapatkan keadaan umum penderita baik, kesadaran kompos mentis. Denyut nadi $120 \mathrm{kali} / \mathrm{menit}$, respirasi $28 \mathrm{kali} / \mathrm{menit}$, dan temperatur aksila $37,3^{\circ} \mathrm{C}$. Berat badan $8 \mathrm{~kg}$ dan tinggi badan $75 \mathrm{~cm}$. Pada status generalis didapatkan kepala normosefali, frontal bossing, saddle nose, dagu yang tampak lancip, pertumbuhan rambut jarang, dan pada kedua mata tidak ditemukan tanda anemia dan ikterus (Gambar 1). Pemeriksaan telinga, hidung, dan tenggorokan didapatkan kesan tenang dan pada leher tidak didapatkan pembesaran kelenjar getah bening. Pada pemeriksaan thoraks didapatkan suara jantung dan paru dalam batas normal. Pada pemeriksaan abdomen tidak didapatkan adanya distensi, bising usus terdengar dalam batas normal. Tidak didapatkan pembesaran kelenjar getah bening inguinal. Pada ekstremitas atas dan bawah tidak didapatkan edema dan teraba hangat. Pada pemeriksaan kuku tidak ditemukan adanya kelainan. Pemeriksaan rongga mulut tidak ditemukan adanya gigi (Gambar 2).

Status dermatologis, lokasi pada seluruh tubuh, didapatkan effloresensi berupa makula hipopigmentasi multipel, batas tegas, bentuk bulat, ukuran $\varnothing 0,5-1 \mathrm{~cm}$, juga didapatkan adanya anhidrosis (Gambar 3). Pada kulit kepala didapatkan adanya alopecia, pada beberapa area terdapat pertumbuhan 
rambut yang jarang (Gambar 4). Pada alis mata didapatkan madarosis.

Pemeriksaan darah lengkap pada tanggal 6 April 2016 didapatkan leukosit 7,37 (6-14 x 10 $/ \mu \mathrm{L})$, neutrofil $3,82\left(1,1-6,6 \times 10^{3} / \mu \mathrm{L}\right)$, limfosit 4,32 $\left(1,8-9,0 \times 10^{3} / \mu \mathrm{L}\right)$, monosit $1,19\left(0,1-1,2 \times 10^{3} / \mu \mathrm{L}\right)$, eosinofil $\quad 0,31 \quad\left(0-0,5 \quad \times 10^{3} / \mu \mathrm{L}\right)$, basofil 0,03 $\left(0-0,1 \times 10^{3} / \mu \mathrm{L}\right)$, hemoglobin 12,44 (12-16 g/dl), hematokrit 37 (36-46\%), trombosit 144,3 $\left(140-440 \times 10^{3} \mu \mathrm{L}\right)$.

Diagnosis kerja pada penderita adalah displasia ektodermal tipe hipohidrotik. Pasien menjalani rawat jalan, dengan penatalaksanaan berupa krim Noroid (pseudoceramide, phytosterols, stearic acid, vegetable oil, squalene) tiap 12 jam topikal untuk melembabkan kulit yang kering. Rencana dilakukan pemeriksaan biopsi kulit untuk menunjang diagnosis.

Pada bagian Pediatri didiagnosa dengan suspek displasia ektodermal dengan status gizi baik. Penatalaksanaan yang diberikan berupa pemberian zinc $20 \mathrm{mg}$ tiap 24 jam per oral. Pasien rencana dikonsulkan ke bagian ilmu kesehatan gigi dan mulut untuk penatalaksanaan anodontia.

\section{PENGAMATAN LANJUTAN I}

Tidak ada lesi baru, masih didapatkan lesi hipopigmentasi di dada dan punggung. Pasien tidak dikeluhkan adanya kejang, panas badan kadang dirasakan saat suasana lingkungan yang panas. Masih tidak didapatkan pertumbuhan gigi, rambut di kepala masih terlihat jarang.

Pada status present didapatkan keadaan umum penderita kompos mentis. Denyut nadi 100 kali/ menit, respirasi $26 \mathrm{kali} /$ menit, dan temperatur aksila $37,5^{\circ} \mathrm{C}$. Pada status generalis didapatkan kepala normosefali, frontal bossing, saddle nose, dagu yang tampak lancip, pertumbuhan rambut jarang, dan pada kedua mata tidak ditemukan tanda anemia dan ikterus. Pemeriksaan telinga, hidung, dan tenggorokan didapatkan kesan tenang dan pada leher tidak didapatkan pembesaran kelenjar getah bening. Pada pemeriksaan thoraks didapatkan suara jantung dan paru dalam batas normal. Pada pemeriksaan abdomen tidak didapatkan adanya distensi, bising usus terdengar dalam batas normal. Tidak didapatkan pembesaran kelenjar getah bening inguinal. Pada ekstremitas atas dan bawah tidak didapatkan edema dan teraba hangat. Pada pemeriksaan kuku tidak ditemukan adanya kelainan. Pemeriksaan rongga mulut tidak ditemukan adanya gigi.

Status dermatologis, lokasi pada seluruh tubuh, didapatkan effloresensi berupa makula hipopigmentasi multipel, batas tegas, bentuk bulat, ukuran $\varnothing 0,5-1 \mathrm{~cm}$, juga didapatkan adanya anhidrosis
(Gambar 5). Pada kulit kepala didapatkan adanya alopecia, pada beberapa area terdapat pertumbuhan rambut yang jarang (Gambar 6). Pada alis mata didapatkan madarosis.

Diagnosis kerja pada penderita adalah follow up displasia ektodermal tipe hipohidrotik. Penatalaksanaan yaitu berupa krim Noroid (pseudoceramide, phytosterols, stearic acid, vegetable oil, squalene) tiap 12 jam topikal untuk melembabkan kulit yang kering.

Pada bagian Pediatri didiagnosa dengan suspek displasia ektodermal dengan status gizi baik. Penatalaksanaan yang diberikan berupa pemberian zinc $20 \mathrm{mg}$ tiap 24 jam per oral.

\section{PEMBAHASAN}

Displasia ektodermal tipe hipohidrotik merupakan tipe DE yang paling sering dijumpai, ditandai dengan adanya kelainan struktur ektodermal termasuk penurunan fungsi kelenjar keringat. Ektoderm sendiri merupakan salah satu dari 3 lapisan germinal embrio, dimana pada tiga minggu kehidupan akan mengalami pembelahan menjadi ektoderm eksterna dan neuroektoderm. Neuroektoderm akan berkembang menjadi sistem saraf, sedangkan ektoderm eksterna merupakan asal dari epidermis, adneksa, dan enamel gigi. ${ }^{2}$ Oleh karena itu, lapisan ektoderm merupakan cikal bakal bagi perkembangan berbagai macam struktur seperti rambut, gigi, kuku, kelenjar keringat, sistem saraf pusat, sistem saraf perifer, mata, hidung, telinga, kelenjar ekrin, mammae, dan pituitari. ${ }^{1,5}$

Displasia ektodermal tipe hipohidrotik disebabkan karena adanya mutasi pada gen EDA, EDAR dan EDARADD. Gen yang bertanggung jawab pada DE hipohidrotik ini terpeta pada kromosom 2q11 - q13.10. Gen EDA, EDAR dan EDARADD berperan dalam memberikan instruksi terhadap protein-protein yang berperan dalam perkembangan lapisan ektoderm. Protein ini kemudian akan membentuk suatu signaling pathway yang mengatur interaksi antara lapisan ektoderm dan mesoderm yang merupakan dasar bagi pembentukan berbagai macam jaringan dan organ tubuh. ${ }^{1,2,4}$

Pada kebanyakan kasus, DE hipohidrotik disebabkan oleh adanya mutasi pada gen EDA yang diwariskan dalam kromosom X resesif. Karena peyakit ini dibawa oleh kromosom $\mathrm{X}$, maka penderitanya lebih banyak terjadi pada kaum laki-laki yang hanya memiliki satu kromosom X sedangkan pada perempuan harus terjadi di dua kromosom X nya. Pada perempuan, jika hanya satu kromosom saja yang bermutasi maka dirinya menjadi carrier (pembawa gen). Sekitar 70\% kasus yang terjadi adalah pembawa gen (carrier) dengan adanya tanda-tanda atau gejala yang ringan seperti 
beberapa gigi yang hilang atau tidak normal, rambut tipis dan beberapa masalah fungsi kelenjar keringat. Lebih jarang lagi, DE tipe hipohidrotik disebabkan karena adanya mutasi pada gen EDAR atau EDARADD. Adanya mutasi pada gen EDAR dapat diturunkan secara autosomal dominan maupun autosomal resesif, sedangkan mutasi pada gen EDARADD diturunkan secara autosomal resesif. ${ }^{2,3,4}$

Manifestasi klinis DE tergantung dari struktur atau bagian tubuh yang terlibat. Pada keterlibatan rambut dapat berupa pertumbuhan rambut yang jarang, rambut dapat terlihat tipis dan mudah rapuh, alis mata jarang atau tidak ada, bulu mata bisa normal, jarang atau sama sekali tidak ada. Kulit kepala seringkali kering karena jumlah kelenjar sebasea mengalami penurunan sehingga ketombe atau kulit kepala yang bersisik seringkali dijumpai. Rambut ciri seksual sekunder di daerah dagu, pubis dan aksila bervariasi sedangkan di badan dan ekstremitas biasanya tidak ada. Rambut sendiri memiliki berbagai macam peranan penting, antara lain berupa perlindungan terhadap sinar matahari, memberi kehangatan pada tubuh, sensasi raba, maupun fungsi estetika. Adanya abnormalitas pertumbuhan rambut pada penderita $\mathrm{DE}$ dapat menyebabkan gangguan dari fungsi tersebut., $2,5,6$

Pada keterlibatan gigi dapat ditandai dengan absensi atau abnormalitas pertumbuhan gigi. Pertumbuhan gigi juga dapat terhambat, biasanya gigi primer muncul setelah 6 bulan sampai 1 tahun lebih lama dibanding anak sebayanya. Gigi susu dan gigi permanen bisa tidak tumbuh atau hanya tumbuh beberapa. Bentuk gigi seri dan atau taring seperti baji. Pertumbuhan gigi biasanya terlambat dan cenderung berukuran kecil dan jarak antar gigi lebar. Alveolar ridges hipoplasi sehingga menyebabkan bibir terlihat menonjol. Karies gigi dan maloklusi sering menjadi masalah. ${ }^{6,8}$

Kelenjar pituitari termasuk salah satu derivat ektoderm. Kelenjar ini berperan penting dalam sintesa berbagai macam hormon yang penting bagi tubuh kita, seperti Human Growth Hormone (HGH), Thyroid Stimulating Hormone (TSH), Adrenocorticotropic Hormone (ACTH) maupun Melanocyte Stimulating hormone (MSH). Pada DE bisa ditemukan adanya abnormalitas kelenjar pituitari sehingga dapat menyebabkan kelainan berupa hambatan perkembangan, hipotiroid, insufisiensi ginjal, hipoglikemia, dan sebagainya., ${ }^{3,10}$

Anak-anak dengan DEH biasanya memiliki berat badan yang lebih rendah dari anak sebayanya, ditandai dengan BMI (Body Mass Index) yang kurang dari normal dan lemak subkutan yang tipis. Hal ini disebabkan karena absensi dari gigi atau pertumbuhan gigi yang abnormal dan produksi air liur yang menurun dapat membuat anak menjadi kesulitan dalam mengunyah makanan. Anak dengan DEH biasanya juga memiliki kesulitan menelan makanan dan kecenderungan untuk muntah. ${ }^{1,2,5}$ Selain itu, abnormalitas kelenjar pituitari juga dapat menyebabkan pertumbuhan anak menjadi terhambat.

Pada keterlibatan kelenjar keringat ditandai dengan absensi atau penurunan jumlah kelenjar keringat ekrin sehingga produksi keringat menurun atau bahkan tidak diproduksi sama sekali. Abnormalitas produksi keringat ini menyebabkan tubuh tidak mampu meregulasi temperatur tubuh secara normal sehingga sering didapatkan demam pada penderita, terutama pada suasana yang panas dan aktivitas yang berat. Adanya demam ini dapat menyebabkan manifestasi kelainan neurologis seperti kejang., ${ }^{2,6}$

Pada kelainan kuku dapat memberikan tanda seperti tidak adanya lempeng kuku, pertumbuhan lempeng kuku yang terhambat, lempeng kuku menjadi distrofi, rapuh, dan berwarna kepucatan., ${ }^{1,7}$

Kelainan pada mata disebabkan karena adanya konstriksi duktus kelenjar lakrimal maupun penurunan jumlah kelenjar lakrimal. Hal ini menyebabkan mata menjadi kering sehingga dapat terjadi inflamasi, sensitivitas terhadap cahaya yang bertambah, hingga sampai kerusakan kornea. Kelainan lain yang dapat terjadi seperti strabismus, blepharophimosis, entropion, dakriosistitis, maupun penurunan fungsi kelenjar Meibom. Penelitian oleh Keklikci et all melaporkan bahwa sekitar $88,9 \%$ pasien memiliki hiperpigmentasi periorbita, kelainan alis mata didapatkan pada $88,9 \%$ pasien, dan mata kering pada $61,1 \%$ pasien. Selain itu juga diketahui bahwa manifestasi kelainan pada mata meningkat seiring bertambahnya usia. ${ }^{1,2,9}$

Pendengaran juga dapat terganggu karena terjadi sumbatan akibat akumulasi serumen. Hal ini dapat meningkatkan terjadinya resiko infeksi terutama bagian telinga tengah. Dapat pula terjadi gangguan penciuman dan indera perasa karena kelainan fungsi atau absensi kelenjar saliva yang menyebabkan penurunan jumlah air liur. Absensi kelenjar mukus pada hidung dan tenggorokan dapat menyebabkan kekeringan sehingga meningkatkan resiko infeksi pada saluran pernafasan. Kekeringan pada mulut dan absensinya gigi dapat pula menyebabkan gangguan bicara pada penderita. ${ }^{8,9}$

Pada kasus, dari anamnesis didapatkan bahwa pada awalnya penderita dikeluhkan kulit tidak pernah berkeringat sejak lahir. Pasien juga tidak memiliki rambut kepala dan alis sejak lahir, saat berusia 1 tahun mulai tumbuh rambut di kepala namun jarang. Selain itu, sampai sekarang pasien juga dikeluhkan tidak tumbuh gigi. Keluhan demam hilang timbul sejak pasien lahir. Demam 


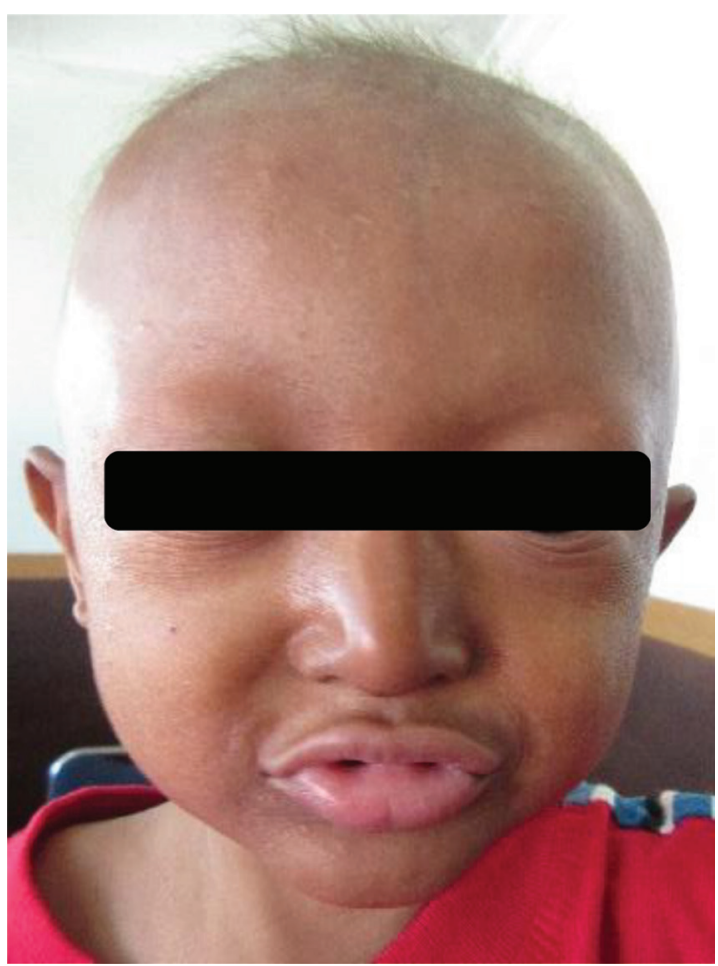

Gambar 1 Pada wajah pasien dapat dilihat adanya frontal bossing, saddle nose, dan dagu yang lancip yang merupakan ciri khas dari displasia ektodermal

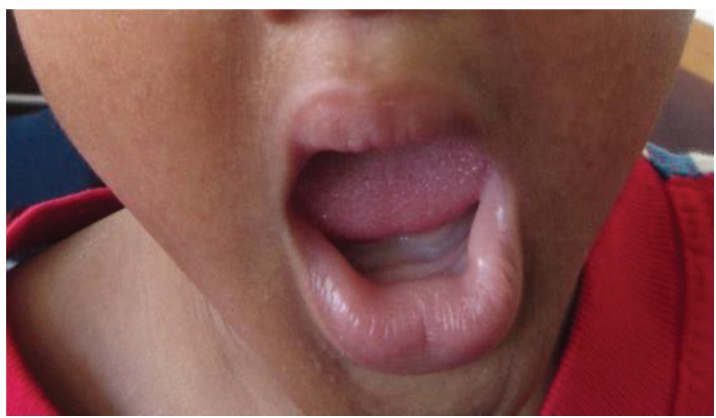

Gambar 2 Menunjukkan tidak adanya gigi (anodontia) pada pasien

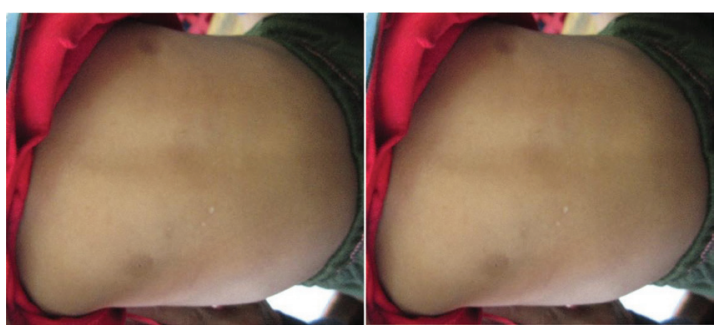

Gambar 3 Makula hipopigmentasi multipel pada bagian dada dan punggung

sering terjadi bila cuaca panas dan saat pasien melakukan aktivitas berlebih. Pada pemeriksaan fisik didapatkan keadaan umum penderita baik, kesadaran kompos mentis. Denyut nadi 120 kali/ menit, respirasi $28 \mathrm{kali} / \mathrm{menit}$, dan temperatur

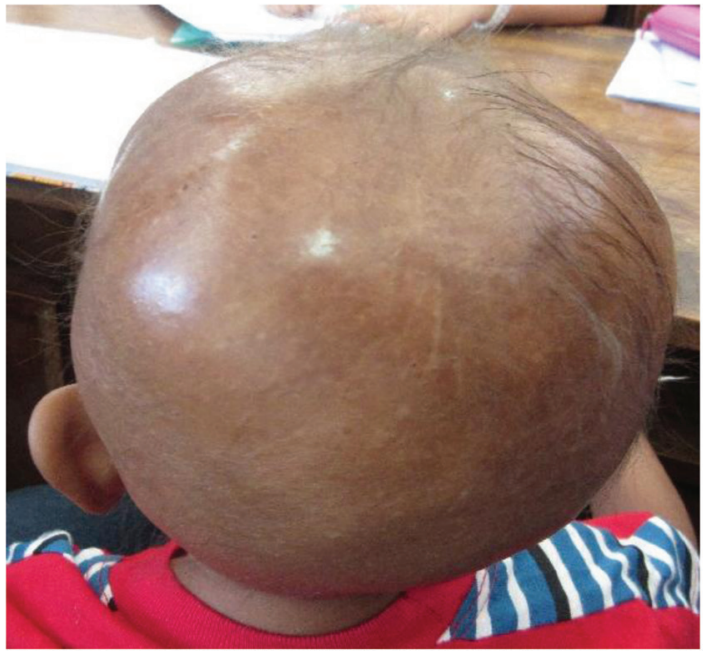

Gambar 4 Menunjukkan adanya alopecia dan pada beberapa area terdapat pertumbuhan rambut yang jarang
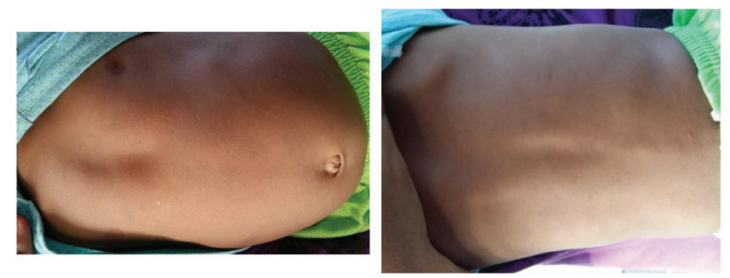

Gambar 5 Makula hipopigmentasi multipel pada bagian dada dan punggung

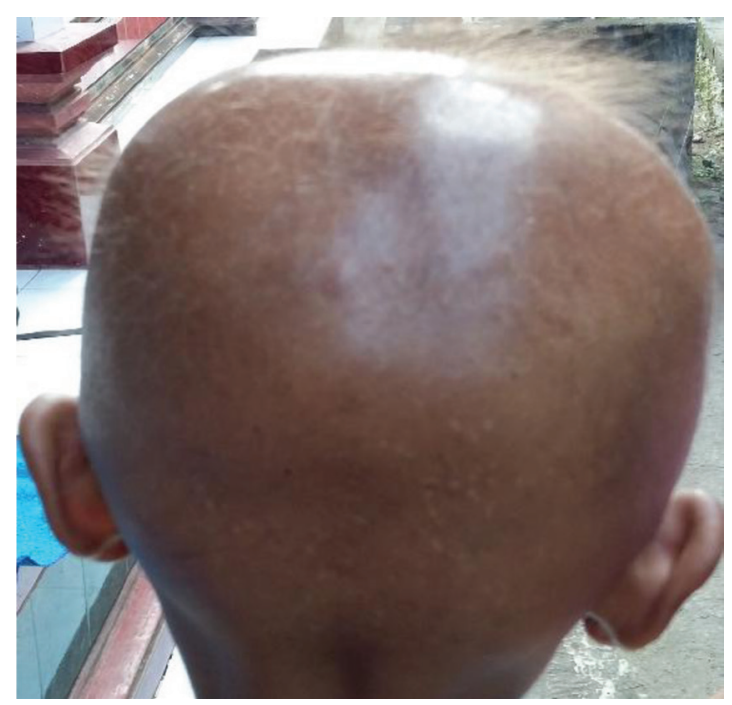

Gambar 6 Menunjukkan adanya alopecia dan pada beberapa area terdapat pertumbuhan rambut yang jarang

aksila $37,3^{\circ} \mathrm{C}$. Dari status dermatologis, lokasi pada seluruh tubuh, didapatkan effloresensi berupa makula hipopigmentasi multipel, batas tegas, bentuk bulat, ukuran $\varnothing 0,5-1 \mathrm{~cm}$, juga didapatkan adanya anhidrosis. Pada kulit kepala didapatkan adanya alopecia, pada beberapa area terdapat 
pertumbuhan rambut yang jarang. Pada alis mata didapatkan adanya madarosis.

Pemeriksaan laboratorium DEH bersifat tidak spesifik dan kurang berperan dalam penegakan diagnosis. Pada pasien DEH yang disertai imunodefisiensi bisa ditemukan adanya hipogammaglobulinemia, selain itu kadar Ig E serum dapat pula meningkat mirip keadaan atopi. ${ }^{7}$ Pada pemeriksaan foto panoramik bisa ditemukan adanya anodontia atau hipodontia, impaksi, abnormalitas pertumbuhan (bentuk gigi seri dan atau taring seperti baji), maupun enamel gigi yang hipoplastik. Pemeriksaan foto $X$-ray pada tangan maupun kaki bisa menunjukkan adanya deformitas skeletal. Pemeriksaan penunjang lainnya adalah sweat pore counts, iontoforesis pilokarpin dan biopsi kulit. ${ }^{1,5}$

Pemeriksaan sweat pore counts dapat dilakukan dengan menggunakan bubuk starch-iodine. Pada orang normal, adanya keringat akan merubah warna kuning bubuk starch-iodine menjadi warna ungu sehingga pori-pori kulit dapat dievaluasi. Pada penderita DEH terdapat visualisasi yang kurang dari pori-pori kulit, dimana dapat dilihat adanya area hipohidrosis yang mengikuti garis Blaschko.

Pada wanita yang menjadi karier, dapat dilihat adanya gambaran mosaic dimana area dengan kelenjar keringat yang normal dengan area tanpa kelenjar keringat tampak berselang-seling. ${ }^{1,5,6}$

Pada pemeriksaan histopatologi didapatkan adanya gambaran penurunan jumlah kelenjar keringat, folikel rambut, dan kelenjar sebasea. Pada DE hipohidrotik epidermis tampak tipis dan jumlah kelenjar keringat ekrin dan apokrin hanya sedikit atau rudimenter. Jaringan konektif dermis biasanya terlihat normal tetapi serabut kolagen dan elastin terpotong- potong atau sedikit. Pada pemeriksaan helai rambut dengan mikroskop elektron didapatkan kelainan bervariasi termasuk adanya celah atau alur longitudinal dan transversal, serta atrofi bulbus. ${ }^{4,6,7}$

Pada kasus tidak dilakukan pemeriksaan biopsi kulit karena ibu pasien menolak dilakukan tindakan karena masalah biaya.

Salah satu diagnosis banding DE adalah alopecia universalis. Pada alopecia universalis terjadi kehilangan rambut baik rambut kepala maupun rambut lainnya pada tubuh. Tidak seperti DE hipohidrotik, hilangnya rambut pada alopecia universalis tidak disertai dengan defek pada struktur ektodermal lainnya seperti gigi, kuku, maupun kelenjar keringat. Pada pemeriksaan histopatologi ditemukan jumlah folikel rambut yang mengalami penurunan, penipisan dari batang rambut dan infiltrat inflamatorik perifolikuler. ${ }^{11}$

Diagnosa banding lainnya adalah focal dermal hypoplasia (FDH). FDH merupakan kelainan genetik yang diturunkan secara X-linked oleh karena adanya mutasi pada gen PORCN. Seperti DE, pada FDH bisa dijumpai adanya alopecia, kelainan pada kuku maupun gangguan pertumbuhan gigi, tetapi dapat dibedakan dengan adanya lesi berupa garis hipoplastik linier yang mengikuti garis Blaschko dan kecenderungan penderita untuk mengalami hiperhidrosis. Pada pemeriksaan histopatologi bisa didapatkan penipisan dari lapisan dermis, adanya serabut kolagen tipis pada papila dermis, dan kumpulan adiposit pada dermis. ${ }^{12}$

Tidak ada pengobatan yang spesifik untuk DE, dimana pengobatannya lebih bersifat simptomatis. Pasien pada umumnya tidak dirawat oleh seorang dokter saja, namun beberapa dokter termasuk dokter gigi. Penderita dengan abnormalitas produksi keringat dianjurkan untuk tinggal di lingkungan dengan suasana yang sejuk atau dengan menggunakan air conditioning di rumah, pasien juga dianjurkan untuk sering membasahi dirinya atau mandi dengan menggunakan air dingin untuk mempertahankan temperatur tubuh. ${ }^{2,3}$ Pada keadaan kulit kering dan bersisik, penggunaan emolien sangat dianjurkan. Intervensi dini yang teratur terhadap pertumbuhan gigi sangat penting untuk artikulasi, pertumbuhan dan penampilan. Anak diajarkan pentingnya menjaga kebersihan gigi untuk mencegah karies dan tanggalnya gigi yang ada, jika perlu dilakukan implan gigi. ${ }^{1,4}$ Penggunaan wig dapat dianjurkan bagi pasien dengan pertumbuhan rambut yang jarang atau pada kasus yang didapatkan alopecia. Air mata buatan dapat diberikan untuk mencegah terjadinya kekeringan pada mata dan meminimalisir defek pada kornea. Terapi pembedahan dapat dilakukan untuk memperbaiki deformitas wajah. Kebanyakan penderita DE memiliki angka harapan hidup yang sama dengan orang normal dan memiliki produktivitas yang baik ketika mereka sudah mengerti bagaimana cara beradaptasi dengan keadaannya tersebut. ${ }^{1,2,3}$

Pada kasus, pasien diberikan emolien untuk mengatasi keadaan kulit kering. Ibu pasien dianjurkan untuk memakaikan pakaian yang tidak terlalu ketat dan sejuk pada anaknya, memandikan anaknya secara berkala dengan air dingin, dan menjaga agar lingkungan tetap sejuk.

\section{SIMPULAN}

Telah dilaporkan satu kasus displasia ektodermal hipohidrotik pada pasien berusia 1 tahun. Diagnosis ditegakkan berdasarkan anamnesis dan pemeriksaan fisik. Dari anamnesis didapatkan bahwa pada awalnya penderita dikeluhkan kulit tidak pernah berkeringat sejak lahir. Pasien juga tidak memiliki rambut kepala dan alis sejak lahir, 
saat berusia 1 tahun mulai tumbuh rambut di kepala namun jarang. Selain itu, sampai sekarang pasien juga dikeluhkan tidak tumbuh gigi. Keluhan demam hilang timbul sejak pasien lahir. Demam sering terjadi bila cuaca panas dan saat pasien melakukan aktivitas berlebih. Pada pemeriksaan fisik didapatkan keadaan umum penderita baik, kesadaran kompos mentis. Dari status dermatologis, lokasi pada seluruh tubuh, didapatkan effloresensi berupa makula hipopigmentasi multipel, batas tegas, bentuk bulat, ukuran $ø 0,5-1 \mathrm{~cm}$, juga didapatkan adanya anhidrosis. Pada kulit kepala didapatkan adanya alopecia, pada beberapa area terdapat pertumbuhan rambut yang jarang. Pada alis mata didapatkan adanya madarosis. Tatalaksana yang diberikan berupa pemberian emolien untuk mengatasi keadaan kulit kering. Ibu pasien dianjurkan untuk memakaikan pakaian yang tidak terlalu ketat dan sejuk pada anaknya, memandikan anaknya secara berkala dengan air dingin, dan menjaga agar lingkungan tetap sejuk.

\section{ETIK DALAM PENELITIAN}

Penelitian ini telah mendapatkan persetujuan tertulis pada orang tua pasien (signed inform consent) bahwa laporan kasus ini akan dilakukan publikasi pada jurnal ilmiah kedokteran.

\section{DAFTAR PUSTAKA}

1. Mathur PT, Paul R, Banthia P, Kapoor TJ. Understanding Ectodermal Dysplasia. Indian Journal of Dental Sciences. 2013;4(5):88-90
2. Martín PG, et al. Ectodermal Dysplasias: a Clinical and Molecular Review. Actas Dermosifiliogr. 2013;104:451-70.

3. Nguyen M, Skovbo S, Svaneby D, Pedersen L, Fryzek J. The Prevalence of X-linked Hypohidrotic Ectodermal Dysplasia (XLHED) in Denmark, 1995-2010. Eur J Med Genet. 2013;56(5):236-42.

4. Chicuellar NR, et al. Higher-Than-Expected Prevalence of Hypohidrotic Ectodermal Dysplasia in a Rural Mexican Setting: Report of 20 Cases. International Journal of Dermatology. 2010;49(9):1050-1055.

5. Yavuz I, Baskan Z, Ulku R, Dulgergil TC, Dari O. Ectodermal Dysplasia: Retrospective Study of Fifteen Cases. Arch Med Res. 2006;37(3):403-9.

6. Bree AF, Agim N, Sybert VP. Ectodermal Dysplasia. In: Goldsmith LA et all (editor). Fitzpatrick's Dermatology in General Medicine $8^{\text {th }}$ edition. United States: McGrawwHill. 2012; p. 1691-1702.

7. More CB, Bhavsar K, Joshi J, Varma SN, Tailor M. Hereditary Ectodermal Dysplasia: a Retrospective Study. J Nat Sci Biol Med. 2013;4(2):445-450.

8. Rosa RR, Janeiro MM, Camargo SE. Radiographic Study of Patients With Ectodermal Dysplasia and Partial. Indian J Dent Res. 2012;23:801-5.

9. Keklikci U, Yavuz I, TunikS, Ulku ZB, Akdeniz S. Ophtalmic Manifestations in Patients With Ectodermal Dysplasia Syndromes. Adv Clin Exp Med. 2014;23(4):605-10.

10. Goodman HG et all. Growth and Growth Hormone-A Comparison of Isolated Growth-Hormone Deficiency and Multiple Pituitary-Hormone Deficiencies in 35 Patients with Idiopathic Hypopituitary Dwarfism. N Engl J Med. 1998;278:57-68.

11. Kadam P, Kaushik P. Alopecia Universalis: an Extremely Rare but Probable Adverse Effect of Adalimumab. IOSR Journ of Pharmacy. 2014;4(8):55-57.

12. Ureles SD, Needleman HL. Focal Dermal Hypoplasia Syndrome (Goltz Syndrome): The First Dental Case Report. Am Ac of Ped Dent. 1986;8(3):239-243.

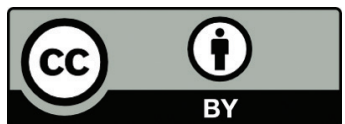

This work is licensed under a Creative Commons Attribution 